\title{
Tentative Practice on Profound Reform of Principles of Landscape Design Course During the COVID-19 Pandemic Period
}

\author{
Xiaojuan Hui ${ }^{1, *}$ \\ ${ }^{1}$ Arts Department, Nankai University Binhai College, Tianjin 300270 China \\ *Corresponding author. Email: 747827540@qq.com
}

\begin{abstract}
This paper introduces the reform and exploration of the teaching mode of Landscape Design course when the scheduled time for the new semester was postponed due to the COVID-19 pandemic. On the one hand, the original theoretical face-to-face teaching content was transformed into online self-study on the "MOSO Teach" platform before class through SPOC (small private online course) blended online and offline flipped classroom, and students were required to submit self-study proof for the preliminary assessment of pre-class learning. The practice in class was mainly presented as online discussion, Q\&A and offline practice training of theoretical learning. On the other hand, according to the difference of students' learning ability and expectation, this reform provided optional learning content and targeted guidance in the practice process, which was helpful to improve their learning initiative and enthusiasm. At the same time, the form of online conference was adopted and achieves the cross-class report and review that was rather difficult to be implemented offline, which received a better teaching effect.
\end{abstract}

Keywords: COVID-19 pandemic, flipped classroom, blended learning, MOSO Teach

\section{INTRODUCTION}

At the beginning of 2020, a pandemic outbreak caused by novel Coronavirus broke out in China. The Ministry of Education issued the "Notice on the Postpone of the Start of the Spring Semester in 2020" on January 27, and the "Guidance on Organize and Management of Online Education in Universities During the Pandemic" on February 4. The Arts Department, Nankai University Binhai College made positive respond immediately, setting up the online teaching guidance working group on February 9, conducting the online teaching technical guidance and discussion work immediately on February 15, and arranging the work requirement of "suspension of school without stopping class" in the spring of 2020. The Landscape Design teaching team of Environmental Design major of the Arts Department in Nankai University Binhai College has carried out blended flipped classroom teaching reform based on SPOC (Small Private Online Course) for the third year of this major by utilizing the quality online teaching resources of MOOC (Massive Open Online Course) for China's Universities.

\section{BLENDED FLIPPED CLASSROOM TEACHING MODEL BASED ON SPOC}

\section{A. SPOC learning mode}

MOOC (Massive Open Online Course) is an online learning model that is free of time and space limitations by use of mobile terminals. However, with the widespread use of MOOC, its defects have become increasingly apparent. In order to solve these defects, Armando Fox of UC Berkeley proposed the SPOC learning mode, which has the following characteristics:

First, online courses are small in size and are taught to a concentrated audience, that is, students who participate in flipped classroom or are interested in the course (private) in the university. The teacher can see the learning effect and progress of students at any time.

Second, on the basis of understanding the teaching objects, teachers can design lecture videos, release relevant non-video learning resources, test learning results, give course assignments or group tasks and manage live discussion and other contents for students' preview before class, review after class or practical application in the form of flipped classroom.

SPOC and flipped classroom can be used for comprehensive teaching, so that the students of this 
college can be the main teaching object and the number of teaching objects can be reduced, so that the teachers can concentrate more on a smaller number of teaching objects, so as to improve the learning effect of students.

\section{B. Flipped classroom}

"Flipped Classroom" was first proposed by J. Berman and A. Ams in the United States. "Flip" refers to the transformation from traditional teaching form in which the teaching of teachers in class are dominant and students do homework after class to the one in which students first learn theoretical knowledge through the online form, and teachers answer questions and discuss what they have learned in class. The core of this form of classroom is students' independent learning, improved participation and interaction, so that students' understanding and application skills of professional theories can be promoted.

The flipped classroom can be classified into three different types of small scale complete flip, large scale flip, small-scale hybrid learning. The main difference lies in the number of students and the specific way of teaching. In the first type, there is a complete reversal of the work done by teachers and students in and out of class. Students learn theoretical knowledge online after class, and have interactive in-depth discussion or theoretical practice with teachers in class. However, a better classroom effect can be ensured when the number of students is below 30. In the second type, teacherstudent interactions are increased, so that the teacher can know the situation of students' learning and understanding at any time in class. In this case, there is a slight reversal of the two roles, which is mainly used for a large-size course. In the third type, the size of the class is between the two above. The teaching method is based on online learning with less interactive face-toface teaching. It requires more initiative of students, with flexible teaching content.

\section{Blended flipped classroom based on SPOC}

The Implementation of SPOC requires the use of a "public cloud" or a "private cloud" to establish an oncampus platform for the course. Teachers can edit the theory teaching videos of SPOC platform or make their own learning videos based on the syllabus and course schedule of the school, so as to make corresponding course and class time arrangement. At the same time, with the online and offline blended learning mode combined, theoretical lecture videos for the courses and relevant non-video learning resources will be used for online learning before class; learning outcomes examination, course assignments or group tasks and indepth discussions, etc. are arranged in offline courses. In this teaching mode, students' theoretical learning is not limited by time and space, and the single learning time is divided into individual knowledge points, so that they can truly learn and review at anytime and anywhere. At the same time, more practice and discussion on theoretical knowledge can be conducted in class to help students consolidate and strengthen theoretical knowledge and practical application.

The "Landscape Design" of the environment design major in the Arts Department of Nankai University Binhai College is a compulsory course for the junior students of this major. This course requires the basic theoretical knowledge teaching of Landscape Design and its application in design practice. To ensure the quality of teaching, the course is carried out in a classbased teaching model with 20-30 students in each class. In the previous teaching process, although students are given practice exercises corresponding to the related theoretical knowledge in each chapter, they tend to grasp less in class and make slow progress in practical work after class. As a result, there is less application of theory in the practice of course closing design, which makes both teachers and students frustrated. In view of the above situation, by use of "MOSO Teach" as the main teaching platform in the fall semester of 2019, the author preliminarily explored the SPOC flipped classroom teaching mode for three professional courses, modified and improved the SPOC flipped classroom teaching mode during the winter vacation of 2020 . Finally, in the spring semester during the pandemic period in March 2020, she implemented the SPOC blended learning course reform in the form of smallscale complete inversion for "Landscape Design".

\section{TEACHING DESIGN OF THE "LANDSCAPE DESIGN" REFORM}

\section{A. The cloud platform of course teaching}

In order to better realize the online teaching of "school suspension without stopping learning" during the pandemic, the author in early February 2020 compared and analyzed the online teaching tools with high usage at that time after classifying them into three categories.

1) Live broadcast teaching tools based on teaching platform: This kind of teaching tool is outstanding in classroom live broadcast (voice or video call can be used), which can realize real-time question answering, interaction and other classroom activities, and has powerful functions in teaching management. Meanwhile, it supports playback and students can learn repeatedly, with representing software such as "Rain Classroom".

2) Live-streaming teaching tools based on social platforms: These teaching tools are relatively stable in operation, easy to master and convenient for real-time communication. However, they have some defects in teaching management, such as assigning homework and 
teaching activities, with representing software such as "Tencent meeting".

3) SPOC based teaching tools: These teaching tools are convenient for students to learn independently, with the functions such as the release of theoretical knowledge and various resources, etc., and support student-student interaction and teacher-student interaction. However, they lack the function of live broadcast, with representing software such as "MOSO Teach".

For the SPOC flipped classroom teaching mode of the "Landscape Design" course, students' theoretical knowledge learning needs to learnt before the class through online means, which can be realized through SPOC teaching tools. Tests used for testing students' grasp of theoretical knowledge, teaching interactions, in-depth exploration and program comments and guidance needed in program design in class can be achieved through teaching platform or social platform live teaching tools. In addition, course-related nonvideo resources can be realized through SPOC teaching tools. Therefore, in view of the above functional requirements, it was finally determined to complete the implementation of this teaching reform with the "MOSO Teach" as the main platform and "Tencent meeting" as supplement.

\section{B. Course design}

The teaching plan of "Landscape Design" is 96 credit hours. The author divides the course into three parts: online theoretical learning before class, online + offline interactive learning in class, and offline practical learning after class. Students are provided with two kinds of learning depth according to their learning ability in terms of theoretical learning content. Among them, online learning before class is mainly for students' self-learning of theoretical knowledge lectures and non-video resources under SPOC platform. This part includes basic theoretical knowledge video learning ( 28 credit hours) and extended theoretical knowledge video learning (10 credit hours). Classroom learning is in online and offline forms. The online form includes the corresponding knowledge test and Q\&A as well as the presentation and comment of design practice and scheme design, with a total of 48 credit hours. Offline learning includes independent practical application and design exercises of students, including basic ability training (26 credit hours) and comprehensive ability training (22 credit hours). Offline learning after class is mainly about assignments and curriculum reflection, etc. The overall curriculum teaching activity design is shown in "Fig. 1".

Before class

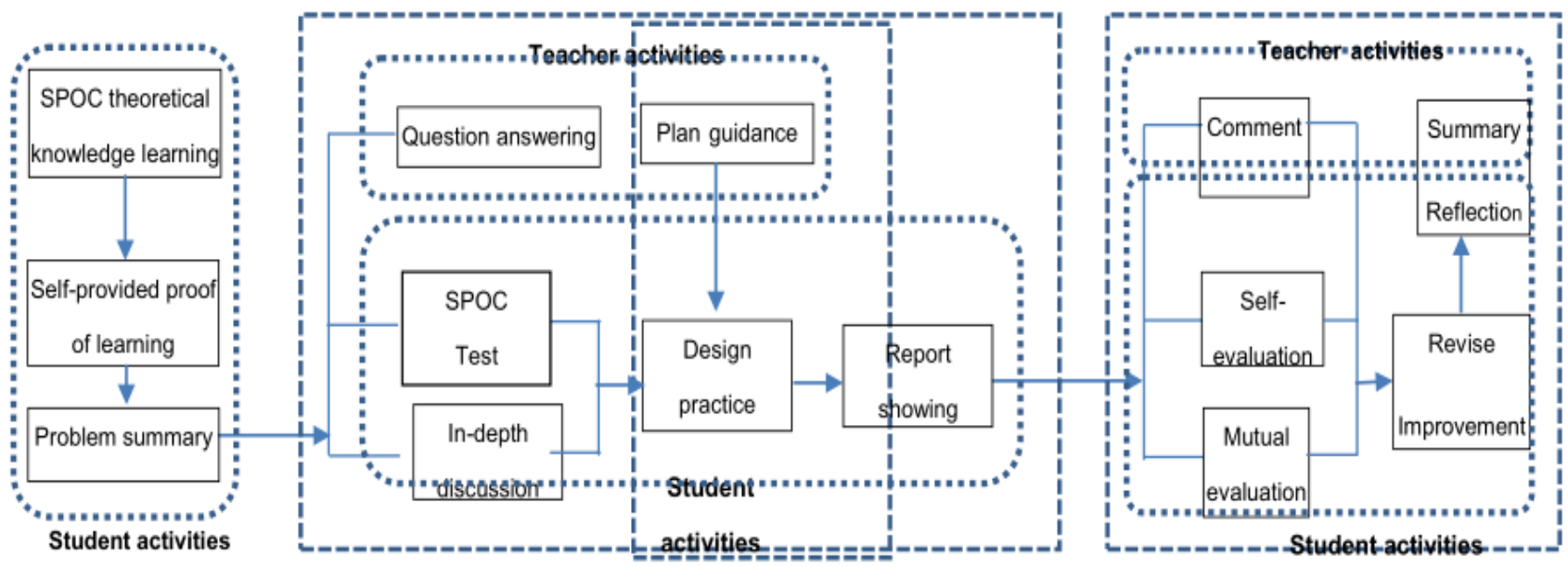

Fig. 1. Overall teaching design of the SPOC blended flipped classroom for the "Landscape Design".

1) Before class: During the teaching process, SPOC theoretical knowledge teaching videos will be released before class and activities of corresponding chapters requiring self-provided proof of learning will be started in "MOSO Teach", which will end before class. The teaching content is mainly MOOCs, and part of the content is recorded by the author. In addition to theoretical videos, non-video supplementary resources for practical activities are released for students to learn (See "Table I" for details). 
TABLE I. STATISTICS OF RESOURCE RELEASED By "MOSO TEACH".

\begin{tabular}{|c|l|l|l|}
\hline Resource type & \multicolumn{1}{|c|}{ Resource content } & \multicolumn{1}{|c|}{ Source of resources } & \multicolumn{1}{|c|}{$\begin{array}{c}\text { Number of } \\
\text { resources }\end{array}$} \\
\hline \multirow{5}{*}{ Video resources } & Topic 1 Site cognition & MOOC editing & 9 \\
\cline { 2 - 4 } & Topic 2 Landscape space generation & MOOC editing & 10 \\
\cline { 2 - 4 } & Topic 3 Public behavior and Landscape Design & MOOC editing & 8 \\
\cline { 2 - 4 } & Topic 4 Highlight the culture of the place ( elective) & MOOC editing & 8 \\
\cline { 2 - 4 } & Topic 5 Design thinking and expression of garden design & MOOC editing & 8 \\
\cline { 2 - 4 } & Basic ability training & recorded by the author & 8 \\
\cline { 2 - 4 } & comprehensive ability training & recorded by the author & 3 \\
\hline \multirow{2}{*}{$\begin{array}{c}\text { Non-video } \\
\text { resources }\end{array}$} & supplementary resources for course activities and tasks & WeChat official account & 24 \\
\cline { 2 - 4 } & other course related supporting resources & $\begin{array}{l}\text { WeChat official account + web } \\
\text { page link }\end{array}$ & 10 \\
\hline
\end{tabular}

TABLE II. DESIGN OF CLASSROOM TEACHING ACTIVITIES AND ALLOCATION OF CLASS HOURS OF "LANDSCAPE DESIGN"

\begin{tabular}{|c|c|c|c|c|c|c|}
\hline \multirow{2}{*}{ Form } & \multirow{2}{*}{$\begin{array}{l}\text { Classroom } \\
\text { activities }\end{array}$} & \multicolumn{2}{|c|}{ COURSE CONTENT } & \multirow{2}{*}{$\begin{array}{l}\text { Use } \\
\text { tool }\end{array}$} & \multicolumn{2}{|c|}{ Credit hour } \\
\hline & & category & programme content & & allocation & summary \\
\hline \multirow{22}{*}{ 产 } & \multirow{11}{*}{ 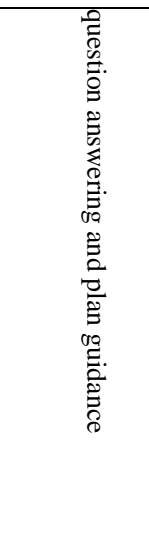 } & \multirow{4}{*}{$\begin{array}{l}\text { basic } \\
\text { required } \\
\text { knowledge }\end{array}$} & Topic 1 Site cognition & \multirow{11}{*}{ 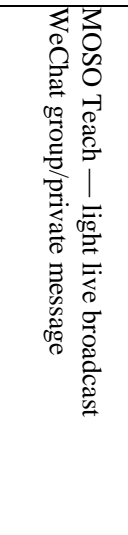 } & 3.5 & \multirow{11}{*}{32.5} \\
\hline & & & Topic 2 Landscape space generation & & 3.5 & \\
\hline & & & Topic 3 Public behavior and Landscape Design & & 3.5 & \\
\hline & & & $\begin{array}{l}\text { Topic } 5 \text { Design thinking and expression of garden } \\
\text { design }\end{array}$ & & 1.5 & \\
\hline & & $\begin{array}{l}\text { Expanding } \\
\text { the elective } \\
\text { knowledge }\end{array}$ & Topic 4 Highlight the culture of the place ( elective) & & 1.5 & \\
\hline & & \multirow{3}{*}{$\begin{array}{l}\text { Basic } \\
\text { competence } \\
\text { training }\end{array}$} & Exercise 1 Basic design elements training & & 2 & \\
\hline & & & Exercise 2 Space composition training & & 6 & \\
\hline & & & $\begin{array}{l}\text { Exercise } 3 \text { Plane extension diagram }+ \text { plane rotation } \\
\text { space training }\end{array}$ & & 2 & \\
\hline & & \multirow{3}{*}{$\begin{array}{l}\text { all-round } \\
\text { ability } \\
\text { development }\end{array}$} & $\begin{array}{l}\text { project design stage } 1 \text { Design philosophy and conceptual } \\
\text { design }\end{array}$ & & 2 & \\
\hline & & & project design stage 2 In-depth design of the plan & & 6 & \\
\hline & & & project design stage 3 design production & & 1 & \\
\hline & \multirow{5}{*}{ 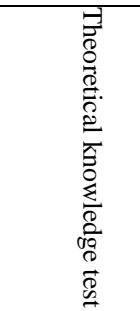 } & \multirow{4}{*}{$\begin{array}{l}\text { basic } \\
\text { required } \\
\text { knowledge }\end{array}$} & Topic 1 Site cognition & \multirow{5}{*}{ 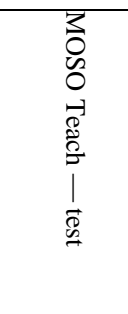 } & 0.5 & \multirow{5}{*}{2.5} \\
\hline & & & Topic 2 Landscape space generation & & 0.5 & \\
\hline & & & Topic 3 Public behavior and Landscape Design & & 0.5 & \\
\hline & & & $\begin{array}{l}\text { Topic } 5 \text { Design thinking and expression of garden } \\
\text { design }\end{array}$ & & 0.5 & \\
\hline & & $\begin{array}{l}\text { Expanding } \\
\text { the elective } \\
\text { knowledge }\end{array}$ & Topic 4 Highlight the culture of the place ( elective) & & 0.5 & \\
\hline & \multirow{6}{*}{ 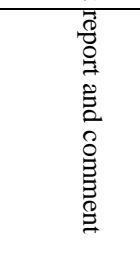 } & \multirow{3}{*}{$\begin{array}{l}\text { Basic } \\
\text { competence } \\
\text { training }\end{array}$} & Exercise 1 Basic design elements training & \multirow{6}{*}{ 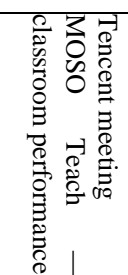 } & 2 & \multirow{6}{*}{13} \\
\hline & & & Exercise 2 Space composition training & & 2 & \\
\hline & & & $\begin{array}{l}\text { Exercise } 3 \text { Plane extension diagram }+ \text { plane rotation } \\
\text { space training }\end{array}$ & & 2 & \\
\hline & & \multirow{3}{*}{$\begin{array}{l}\text { all-round } \\
\text { ability } \\
\text { development }\end{array}$} & $\begin{array}{l}\text { project design stage } 1 \text { Design philosophy and conceptual } \\
\text { design }\end{array}$ & & 2 & \\
\hline & & & project design stage 2 In-depth design of the plan & & 2 & \\
\hline & & & project design stage 3 design production & & 3 & \\
\hline \multirow{6}{*}{ 声 } & \multirow{6}{*}{ 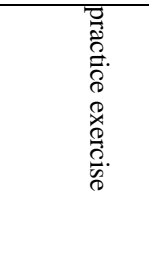 } & \multirow{3}{*}{$\begin{array}{l}\text { Basic } \\
\text { competence } \\
\text { training }\end{array}$} & Exercise 1 Basic design elements training & \multirow{6}{*}{ 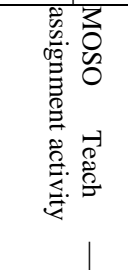 } & 10 & \multirow{3}{*}{26} \\
\hline & & & Exercise 2 Space composition training & & 12 & \\
\hline & & & $\begin{array}{l}\text { Exercise } 3 \text { Plane extension diagram }+ \text { plane rotation } \\
\text { space training }\end{array}$ & & 4 & \\
\hline & & \multirow{3}{*}{$\begin{array}{l}\text { all-round } \\
\text { ability } \\
\text { development }\end{array}$} & $\begin{array}{l}\text { project design stage } 1 \text { Design philosophy and conceptual } \\
\text { design }\end{array}$ & & 4 & \multirow{3}{*}{22} \\
\hline & & & project design stage 2 In-depth design of the plan & & 12 & \\
\hline & & & project design stage 3 design production & & 6 & \\
\hline
\end{tabular}

2) In class: The classroom teaching is conducted in a combination of online + offline learning. Due to the fact that face-to-face teaching cannot be realized during the pandemic, the teacher-student interaction of 
classroom discussion, program guidance and report has been changed to online form. Classroom discussion is conducted through "light live broadcast" in "MOSO Teach", supplemented by WeChat as the classroom record, program guidance and report comments are displayed and communicated through "WeChat" + "Tencent meeting", and student selection and report performance management are conducted through the classroom performance function in "MOSO Teach". In addition to discussion and presentation, the online classroom interaction includes theoretical knowledge learning tests and question answering, both of which are conducted through the "MOSO Teach". Details of learning content and class hours of various online activities can be seen in "Table III". The allocation ratio of various credit hours is discussion and question answering and program guidance: presentation: knowledge test $=13: 5: 1$. Offline classroom activities focus on theoretical application and practice. To ensure the quality and progress of students' offline learning from home during the pandemic, the author arranges the practice part of the class in the form of the "homework and group tasks" in the "MOSO Teach", and submits the results before the end of class on the same day for mutual evaluation, self-criticism among students and comprehensive evaluation by teachers, and carries out comprehensive evaluation of the curriculum results on the same day, so as to facilitate students to modify and improve after class (See "Table II" for the specific offline teaching activities and class hours allocation).

\section{3) After class}

a) Teachers' work after class: Teachers need to use SPOC platform to design detailed course design and teaching log according to the teaching outline and teaching schedule of this course and in combination with students' learning conditions and learning modes during the pandemic period ("Fig. 2"). First of all, teachers need to make detailed designs on theoretical knowledge test questions in class, content of classroom assignments, ways of evaluation activities and motivation for students' learning, etc. Secondly, teachers are required to edit and record video resources of theoretical knowledge of the course. Each video is 58 min long with no more than 3 knowledge points. They should consult relevant literature at any time to release non-video supplementary resources. Thirdly, at the end of each course, teachers should timely evaluate the class tasks completed by students that day and timely release corresponding teaching activities and teaching resources according to the teaching progress. Finally, teachers are required to answer students' questions at any time in the learning process after class through "WeChat".

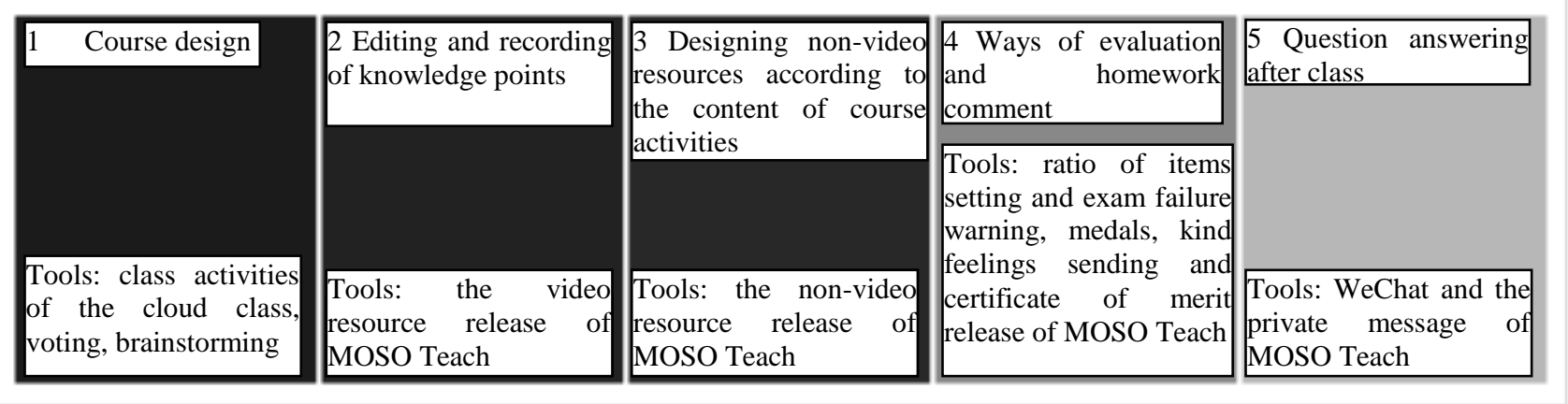

Fig. 2. The work after class of teachers of "Landscape Design".

b) Students' work after class: The content that students need to complete after class mainly includes two parts ("Fig. 3"). The first part is the online theoretical learning content. Students are required to timely study the video and non-video resources released by teachers, and submit the proof of learning. The form of the proof is not mandatory, including but not limited to the form of submitting study notes, learning summary, frame diagram of knowledge theory, etc., in order to show that students have learned and learned the relevant knowledge. The second part is the offline design practice content. Students need to complete the modification and improvement of the design task after class and complete the homework task of "MOSO Teach" after class according to the comments of teachers after class. 


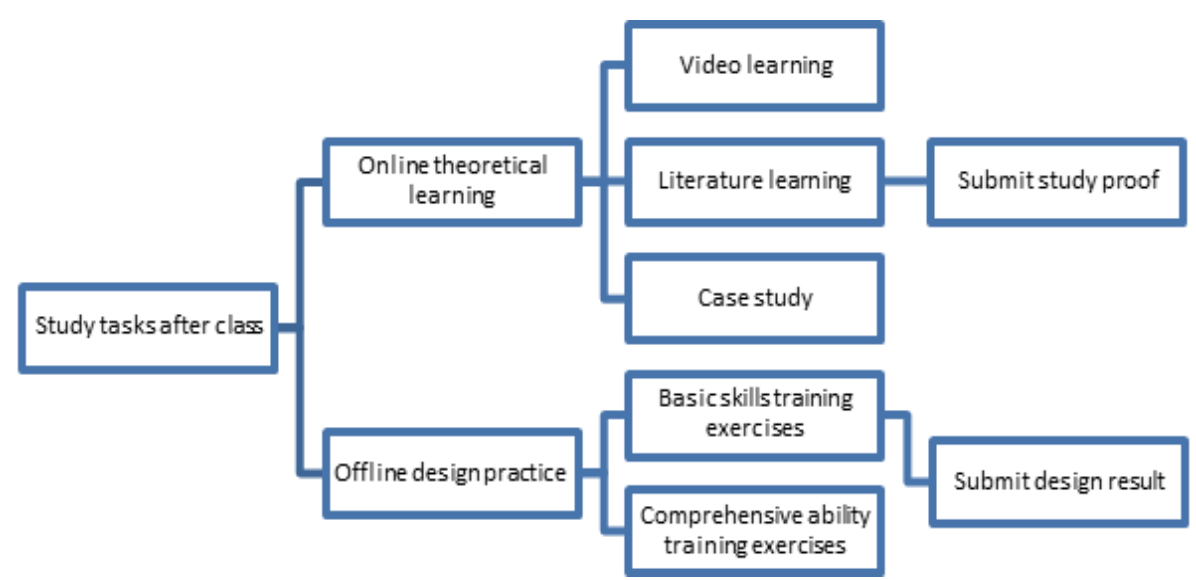

Fig. 3. Study tasks after class for students majoring "Landscape Design".

\section{IMPLEMENTATION EFFECT OF COURSE REFORM}

\section{A. Evaluation mode}

The assessment results of "Landscape Design" are statistically output by empirical statistics of "MOSO Teach", which are divided into four parts for comprehensive assessment - homework tasks, SPOC online learning, classroom activities and other auxiliary activities ("Fig 4"). The first part is the task of operational activities, accounting for $60 \%$ of the comprehensive evaluation, including the training tasks of basic skills training ( 3 exercises) and comprehensive skills training (3 stages), respectively accounting for $20 \%$ and $40 \%$. The result of comprehensive skill training is taken as the final result of the course, and the result will be reported online by the professional director and all teachers of the course group. At the end of the report, the scoring standard was agreed through the "Tencent meeting" and the grades were given. The grades were given on the basis of the horizontal comparison of students' homework results of different classes, so as to ensure the fairness of all classes in the evaluation of the final results. At the same time, the data should represent the situation of different classes, accounting for $24 \%$, and other regular homework assignments were evaluated by the teacher. The second part is SPOC online learning, accounting for $25 \%$ of the comprehensive evaluation, including theoretical knowledge video learning, non-video supplementary resource learning and theoretical knowledge testing, respectively accounting for $15 \%, 5 \%$ and $5 \%$. The third part is the performance of classroom activities, accounting for $11 \%$ of the overall evaluation, including light live broadcast of participation in classroom discussions, class attendance and classroom performance (raising hands, first responders, etc.), respectively $5 \%, 3 \%$ and $3 \%$. The last part is other supporting activities, accounting for $4 \%$ of the total score, including thumb up by teachers, brainstorming and voting and making questionnaire survey, accounting for $2 \%, 1 \%$ and $1 \%$ respectively.
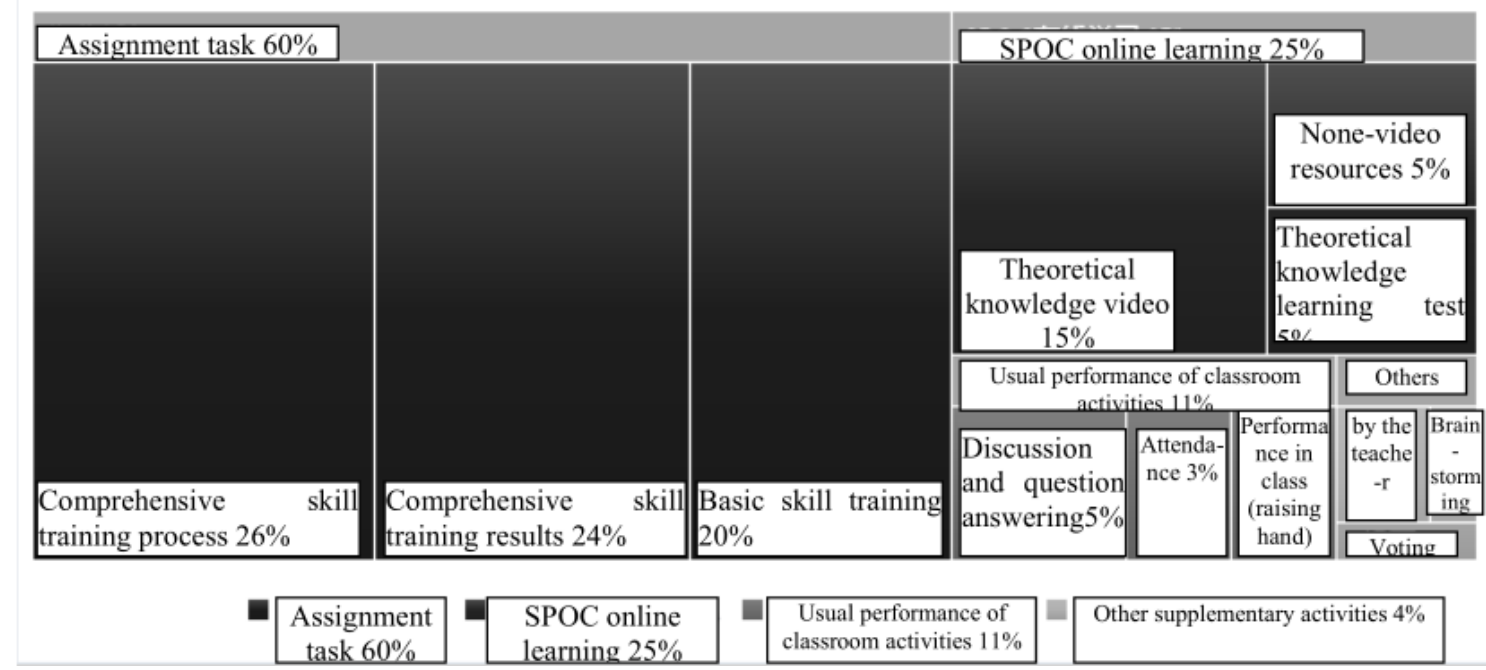

Usual performance of
classroom activities $11 \%$

Other supplementary activities $4 \%$

Fig. 4. The assessment method of the 'land Scape course. 


\section{B. Performance analysis and feedback}

1) Performance analysis: The horizontal comparison between the experimental group and regular classes majoring in Landscape Design without being transformed to SPOC blended flipped classroom in the course group during the same period ("Table III") shows that the classes that implement course reform make better performance in terms of proportion of excellent grades, proportion of passing marks, as well as highest scores, lowest scores and average scores. Among them, the proportion of excellent grade is 10-
$20 \%$ higher than that of the regular class, and the passing grade in the reformed class is $0 \%, 4 \%$ lower than that of the regular class. The highest scores of the reformed classes are 1 point higher than the other two classes, the lowest scores are 6-9 points higher than the other two classes, and the average scores are 1-2 points higher than the other two classes. The above situation shows that the class teaching effect of the reform has been improved to some extent compared with the regular class, which has increased the excellence rate and the rationality of the score distribution of the course.

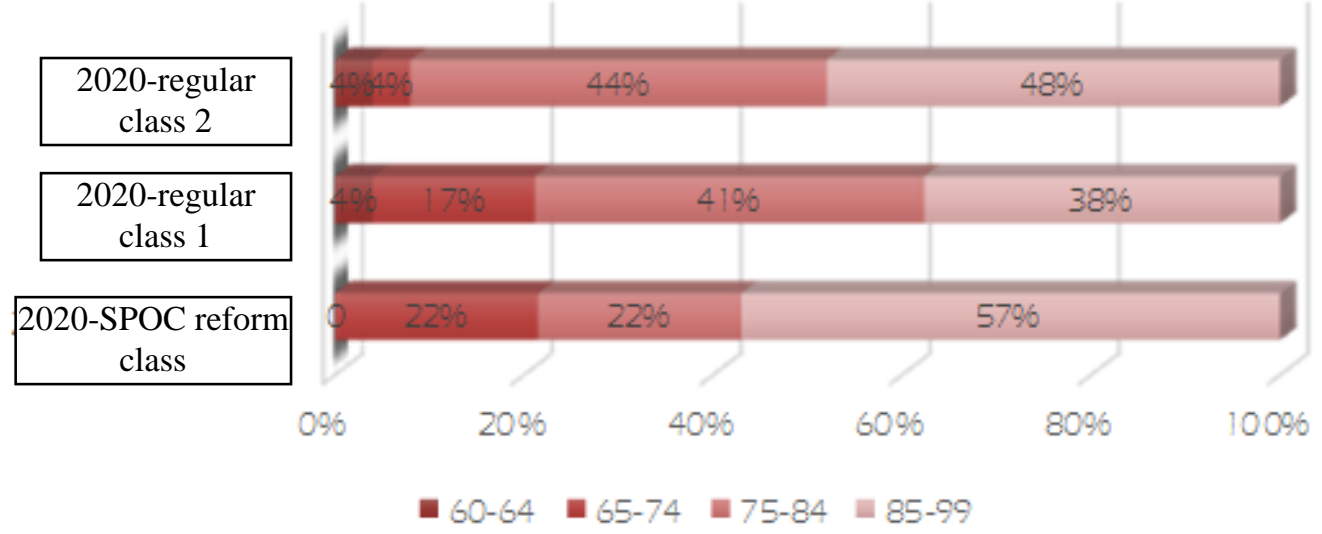

Fig. 5. Comparison of grades between the SPOC reformed classes and those didn't receive reform.

2) Feedback: In the process of SPOC blended flipped classroom, medal, kind feelings, certificates and other forms were used to stimulate students' learning enthusiasm, and various activities were used to enhance students' mastery of knowledge. In order to understand the students' satisfaction with the course reform, the author conducted a class survey through the brainstorming activity of "MOSO Teach". The survey results showed that most of the students approved of this class, and the main views are shown in "Table III".

TABLE III. INVESTIGATION ON THE CLOSING OF CLASSES THAT EXPERIENCED SPOC COURSE REFORM

\begin{tabular}{|l|l|l|}
\hline \multirow{4}{*}{ point 1} & $\begin{array}{l}\text { Improved learning efficiency and time } \\
\text { management ability }\end{array}$ \\
\hline & point 2 & like the form of SPOC blended flipped classroom \\
\hline point 3 & $\begin{array}{l}\text { Compared with the traditional form, the } \\
\text { knowledge capacity is larger }\end{array}$ \\
\cline { 2 - 3 } ADVANTAGES & point 4 & The comprehensive ability has been improved \\
\cline { 2 - 3 } & point 5 & There are more challenges \\
\hline point 6 & $\begin{array}{l}\text { increased communication and exchange with } \\
\text { teachers }\end{array}$ \\
\cline { 2 - 3 } & point 7 & control the learning time by oneslef \\
\cline { 2 - 3 } & point 8 & increased confidence \\
\cline { 2 - 3 } & point 9 & more selfthought and reflection \\
\hline \multirow{2}{*}{ DISADVANTAGES } & point & $\begin{array}{l}\text { It is hoped that the offline interaction can be } \\
\text { resumed after the end of the pandemic. }\end{array}$ \\
\hline
\end{tabular}




\section{REFLECTIONS ON THE COURSE REFORM OF "LANDSCAPE DESIGN"}

Compared with the classroom teaching that haven't experienced course reform, this blended flipped classroom in the form of SPOC transfers the original theoretical teaching part to online autonomous learning before class. This enables students to study at anytime, anywhere and repeatedly, which improves their concentration and knowledge absorption, and further exercises their time management ability. Classroom activities such as discussion, question answering and presentation of reports enhance students' participation and practical ability.

Some problems were also found in the reform process. In general, the implementation of the curriculum reform depends on the following three aspects.

\section{A. Teachers need to do more after-school work}

First of all, by adopting SPOC blended flipped classroom, although MOOC platform videos can be used in the theoretical part, it is difficult to find a MOOC that is completely in line with the teaching plan and teaching schedule of the faculty. Therefore, teachers are required to integrate and edit existing MOOC resources, and supplement and record the parts not covered in MOOC on their own. Secondly, in the offline classroom with this teaching form, students need to participate in all kinds of classroom interaction or practical training, so teachers need to make a lot of meticulous designs, and the total amount is greatly increased compared with the traditional form. Thirdly, due to the interlocking in the course process, teachers are required to have a certain planning and overall design ability to redesign the original courses systematically. Finally, as students' tasks are not only traditional after-class homework, but they are also required to make a lot of practical exercises in class, teachers need to make modifications immediately after the end of the course on that day, so that students can modify and perfect the design scheme after class.

\section{B. The ability of students is greatly improved}

First of all, students need to complete the knowledge study before the teaching in a planned way, and summarize and reflect on the knowledge so as to complete the test activities, in-depth discussion, question answering and practice in class. If they fail to complete the theoretical study well, the test in class will directly reflect their learning situation, and the participation in discussion and question answering will be greatly reduced. Secondly, students need to complete a series of activities and practical homework in class and after class, so the workload of students is larger than in the traditional teaching process.

\section{Part of the benefit to students cannot be quantified}

Compared with traditional teaching methods, most of the workload of students in the course process can be quantified and evaluated, such as students' performance in different aspects. However, the benefits of some abilities cannot be quantified and cannot be easily reflected in performance, such as the substantial increase of students' knowledge reserve, time management ability, expression ability, self-reflection and thinking ability. How to make quantitative evaluation of these abilities is the next issue to consider and solve in teaching.

\section{CONCLUSION}

To sum up, although the process of teaching reform practice is hard, it has achieved initial results. The author hopes that the experience and lessons gained in this process will be helpful to teachers in other ways of reform.

\section{References}

[1] Ministry of Education. Notice on the Postpone of the Start of the Spring Semester in 2020 [EB/OL]. (2020-01-27) [2020-0503].

http://www.moe.gov.cn/jyb_xwfb/gzdt_gzdt/s5987/202001/t202 00127_416672.html. (in Chinese)

[2] Ministry of Education. Guidance issued: Organize and management of Online Education in Universities During the Pandemic [EB/OL]. (2020-02-05) [2020-05-03]. http://www.moe.gov.cn/jyb_xwfb/gzdt_gzdt/s5987/202002/t202 00205_418131.html. (in Chinese)

[3] Zhang Qiang, Zhang Haifeng, Tang Yan, et al. Implementation of flipped classroom based on SPOC Circuit Theory Course [J]. Experimental Technology and Management, 2016, 33(9): 179190, 194. (in Chinese)

[4] Zhu Guiping, Yu Xinjie, Lu Wenjuan. Tentative Practice on Profound Reform of Electric Circuits Course [J]. Journal of EEE, 2013, 35(5): 6-10, 33. (in Chinese)

[5] Zhu Guiping, Yu Xinjie. Active Learning Promotion Strategy Based on Flipped Classroom [J]. Chinese University Teaching, 2018(5): 29-32. (in Chinese)

[6] Yu Xinjie. Study on the Six Relations of Blended Teaching [J]. China University Teaching, 2019(5): 14-18, 28. (in Chinese) 